Research Article

\title{
Study of anti-nociceptive potential of physostigmine and its combination with morphine in albino rats
}

\author{
Rahul P. Bhavasar, Devendra R. Chaudhari*, Bapurao M. Bite, Suyog S. Chopade
}

Department of Pharmacology, Dr. Ulhas Patil Medical College \& Hospital, Jalgaon, Maharashtra, India

Received: 14 September 2015 Accepted: 15 October 2015

\section{*Correspondence to:}

Dr. Devendra R. Chaudhari, Email: devendra7681@gmail.com

Copyright: (C) the author(s), publisher and licensee Medip Academy. This is an open-access article distributed under the terms of the Creative Commons

Attribution Non-Commercial License, which permits unrestricted non-commercial use, distribution, and reproduction in any medium, provided the original work is properly cited.

\begin{abstract}
Background: The cholinergic drugs are having antinociceptive potential but are under investigation because of their serious side effects. It is difficult to accept them as an analgesic. This study is undertaken in the experimental animal models for the evaluation of the antinociceptive potential of Physostigmine and its combination with Morphine at their sub-analgesic doses. The objective of the study was to evaluate the antinociceptive effect of Physostigmine and its combination with subanalgesic dose of morphine and comparing their effect with analgesic dose of Morphine.

Methods: Antinociceptive effect of Physostigmine in three graded doses (50, $100 \& 200 \mu \mathrm{g} / \mathrm{kg})$ and combination of Physostigmine at low dose $(50 \mu \mathrm{g} / \mathrm{kg})$ with sub-analgesic dose of Morphine $(0.1 \mathrm{mg} / \mathrm{kg})$ and Morphine in analgesic dose $(1 \mathrm{mg} / \mathrm{kg})$ was evaluated by using tail flick method in albino rats.

Results: Comparison of maximal possible effect in percentage (MPE in \%) between groups at 90 minutes in control, Morphine, Physostigmine in 50, 100, $200 \mu \mathrm{g} / \mathrm{kg}$ doses and combination group respectively, demonstrated significant difference $(\mathrm{p}<0.001)$ when compared by one way ANOVA test. There was no much increase in the tail flick latency in Physostigmine $50 \mu \mathrm{g} / \mathrm{kg}$ (SC) treatment at $90 \mathrm{~min}(3.08 \pm 0.15)$ in comparison to control (NS) treatment group. Combination treatment of low doses of both Physostigmine $50 \mu \mathrm{g} / \mathrm{kg}+$ Morphine $0.1 \mathrm{mg} / \mathrm{kg}$ increased the tail flick latency $90 \mathrm{~min}(7.08 \pm 0.15)$ incomparison to control (NS) treatment group (3.33 \pm 0.11$)$.

Conclusions: Physostigmine is more potent antinociceptive than Morphine and Physostigmine potentiated the antinociceptive activity of low dose of standard drug Morphine.
\end{abstract}

Keywords: Pain, Antinociceptive, Physostigmine, Morphine, Tail flick

\section{INTRODUCTION}

Pain is an ill-defined, unpleasant sensation usually evoked by an external or internal noxious stimulus experienced by human beings. The taxonomy committee of International Association for the study of pain defines pain as "An unpleasant sensory and emotional experience associated with actual or potential tissue damage or described in terms of such damage". The principal objective of the treatment of pain is to remove or abolish the cause of pain. But it is not always possible to do so. Hence, analgesics are used for the symptomatic treatment of pain. The analgesics are of two types a) opioid and b) non-opioid.
Opioids are the most potent and commonly used group of analgesic drugs mostly used for visceral pain, e.g. Morphine and Pethidine. But their analgesic action is associated with a greater degree of dose dependent adverse drug reactions including drug dependence. ${ }^{2}$

Non-steroidal anti-inflammatory drugs (NSAIDS) are mainly used for treatment of integumental pain and act mainly by peripheral mechanism of action by inhibiting prostaglandin synthesis. These drugs are more effective against pain associated with inflammation and adverse effects like CNS depression and dependence are less when compared to opioids. However these drugs are known to produce gastric irritation including peptic ulceration. Hence there is always a need of development of new analgesics with less adverse effect. 
Several areas distributed throughout the neural axis exert a top-down modulation of pain sensation according to the nature of the painful stimulus and the behavioural state of the individual, both in normal and pathologic conditions. This modulation is largely mediated by descending monoaminergic pathways that either inhibit or facilitate transmission of nociceptive information at the level of the dorsal horn. ${ }^{3-8}$ Monoamines including serotonin, norepinephrine and dopamine act via different receptor subtypes to exert a complex modulation of neurotransmitter release from nociceptive afferents and excitability of dorsal horn neurons. These monoaminergic systems have an important role in mechanisms of inflammatory and neuropathic pain and are a target for pharmacologic management of this conditions. ${ }^{5}$

Recently it has been noticed that Acetylcholine (ACh) is a major excitatory neurotransmitter in the nervous system of vertebrates and invertebrates. ${ }^{9}$ Central cholinergic neurons detected by choline acetyl transferase immunoreactivity are concentrated in the mediobasal forebrain, brainstem, cerebral cortex and hippocampus. Brain cholinergic system through muscarinic receptors may be involved in modulation of pain. ${ }^{10}$ Muscarinic receptor agonists has been demonstrated to be potent and efficacious analgesics in mice. This action of ACh is mediated by the muscarinic ACh receptors (mAChRs). ${ }^{11}$ The cholinesterase inhibitor Physostigmine increased the pain threshold in man. ${ }^{12}$ Muscarinic ACh receptors have also been shown as potential mediators of pain-related neuroplasticity, especially within the spinal cord. Intrathecal administration of cholinergic muscarinic agonists or acetyl cholinesterase inhibitors produces the analgesia in both animals and humans. ${ }^{13}$

The hippocampus is an important part of the mammalian brain, and it is involved in the regulation of many functions, such as memory, learning, avoidance and pain response. Electrophysiological, pharmacological, behavioural and clinical data indicate that the hippocampal formation is an integral component of the limbic system, and plays an important role in the affective and motivational components of pain perception. $^{14}$ The hippocampus receives cholinergic projections from the medial septal nucleus and Broca's diagonal band, which terminate in the CA1, CA3, \& dentate gyrus regions. ${ }^{15}$

Though cholinergic drugs are having antinociceptive potential but are under investigation because of their serious side effects. It is difficult to accept them as an analgesic. This study is undertaken in the experimental animal models for the evaluation of the antinociceptive potential of Physostigmine and its combination with Morphine at their sub-analgesic doses. So that if their combination will show the anti-nociceptive activity then side effects will be less and analgesia will be achieved.

The objective of the study was to evaluate antinociceptive activity of Physostigmine in graded doses and its combination with Morphine at sub analgesic doses by using Radiant heat induced pain by using analgesiometer and to compare its antinociceptive potential with standard drug Morphine.

\section{METHODS}

Wistar albino rats of either sex weighing 150 to 200 gms were selected by the process of randomization. Wistar albino rats were divided into seven groups, each group containing six rats. Instruments required were analgesiometer for tail flick method. Drug Physostigmine was procured from Sigma Aldrich pharmaceuticals India and Morphine sulphate from Troika Pharmaceuticals. Study was performed in the Department of Pharmacology, KIMS, Narketpally; AP. Source of animals was Central animal house, KIMS, Narketpally which were procured from National Institute of Nutrition (NIN), Hyderabad.

Design of the experiment was laboratory based randomized control trial (RCT) with prior permission of Institutional Animal Ethics Committee (IEAC).

Table 1: Grouping of animals and drug schedule.

\begin{tabular}{|llll|}
\hline $\begin{array}{l}\text { Group } \\
\text { No }\end{array}$ & $\begin{array}{l}\text { Groups } \\
\text { Each group N = 6 }\end{array}$ & Drug & $\begin{array}{l}\text { Dose and route of } \\
\text { administration }\end{array}$ \\
\hline 1 & Control & Normal saline & $0.5 \mathrm{ml} / \mathrm{rat} \mathrm{i.p}$ \\
\hline 2 & Sub analgesic dose of Standard & Morphine & $0.1 \mathrm{mg} / \mathrm{kg} \mathrm{i.p}$ \\
\hline 3 & Analgesic dose Standard & Morphine & $1 \mathrm{mg} / \mathrm{kg} \mathrm{i.p}$ \\
\hline 4 & Test drug & Physostigmine & $50 \mu \mathrm{g} / \mathrm{kg} \mathrm{s.c}$ \\
\hline 5 & Test drug & Physostigmine & $100 \mu \mathrm{g} / \mathrm{kg} \mathrm{s.c}$ \\
\hline 6 & Test drug & Physostigmine & $200 \mu \mathrm{g} / \mathrm{kg} \mathrm{s.c}$ \\
\hline 7 & Combination with Test drug & $\begin{array}{l}\text { Physostigmine }+ \text { morphine sub } \\
\text { analgesic dose }\end{array}$ & $\begin{array}{l}50 \mu \mathrm{g} / \mathrm{kg} \mathrm{s.c}+0.1 \mathrm{mg} / \mathrm{kg} \\
\text { i.p }\end{array}$ \\
\hline
\end{tabular}

i.p $=$ intraperitoneal, $s . c=$ subcutaneous. 


\section{Tail flick method}

The instrument used in this method was Analgesiometer. This test was performed only on those rats that had shown the reaction time less than 6 seconds. The cut off time was taken as 10 seconds to avoid the injury to the sensory nerve endings. Wistar albino rats of either sex were selected by the process of randomization and placed in separate cages. After selecting the rats the drug was administered and the reaction time was recorded at 0 min (basal level i.e. immediately after administration of drug) $15 \mathrm{~min}, 30 \mathrm{~min}, 60 \mathrm{~min}$ and at $90 \mathrm{~min}$ of administration of drug. Reaction time between 6 sec to 10 seconds was considered as antinociceptive effect.

\section{Statistical analysis}

One way ANOVA was applied only to maximal possible effect in percentage at $90 \mathrm{~min}$ by using software SPSS v19. It was used for calculation for statistical significance in between groups. $p$ value $<0.05$ is considered as statistically significant.

\section{RESULTS}

Tail flick latency in seconds of normal saline as control group in 6 rats at $0 \mathrm{~min}, 15 \mathrm{~min}, 30 \mathrm{~min}, 60 \mathrm{~min} \& 90$ minutes showed no significant difference when their mean is calculated. Like this reading are taken from all groups and compared. Only mean readings are considered in further for comparison and calculation (Table 1).

Table 2: Tail flick latency in seconds of normal saline (NS) $0.5 \mathrm{ml}$ intraperitoneally (control group).

\begin{tabular}{|c|c|c|c|c|c|}
\hline SL NO & Tail Fl & $\mathrm{y}$ in seco & & & \\
\hline & $0 \mathrm{~min}$ & $15 \mathrm{~min}$ & $30 \mathrm{~min}$ & $60 \mathrm{~min}$ & $90 \mathrm{~min}$ \\
\hline 1 & 3.00 & 3.00 & 3.00 & 3.50 & 3.50 \\
\hline 2 & 2.50 & 2.50 & 3.00 & 3.00 & 3.00 \\
\hline 3 & 3.00 & 3.00 & 3.50 & 3.00 & 3.50 \\
\hline 4 & 3.00 & 3.50 & 3.00 & 3.50 & 3.50 \\
\hline 5 & 3.00 & 3.00 & 3.50 & 3.00 & 3.00 \\
\hline 6 & 3.00 & 3.50 & 3.50 & 3.00 & 3.50 \\
\hline Total & 17.50 & 18.50 & 19.50 & 19.00 & 20.00 \\
\hline Mean & 2.92 & 3.08 & 3.25 & 3.17 & 3.33 \\
\hline SD & 0.20 & 0.38 & 0.27 & 0.26 & 0.26 \\
\hline SE & 0.08 & 0.15 & 0.11 & 0.11 & 0.11 \\
\hline
\end{tabular}

Table 3: Comparison of mean tail flick latency in seconds of physostigmine with different groups (mean $\pm \mathrm{SE}$ ).

\begin{tabular}{|llllll|}
\hline & $\mathbf{0} \mathbf{m i n}$ & $\mathbf{1 5} \mathbf{m i n}$ & $\mathbf{3 0} \mathbf{m i n}$ & $\mathbf{6 0} \mathbf{m i n}$ & $\mathbf{9 0} \mathbf{m i n}$ \\
\hline Control $(\mathrm{NS})$ & $2.92 \pm 0.08$ & $3.08 \pm 0.15$ & $3.25 \pm 0.11$ & $3.17 \pm 0.11$ & $3.33 \pm 0.11$ \\
\hline Morphine $(0.1 \mathrm{mg} / \mathrm{kg})$ & $2.83 \pm 0.11$ & $3.08 \pm 0.15$ & $3.25 \pm 0.11$ & $3.17 \pm 0.11$ & $3.33 \pm 0.11$ \\
\hline Morphine $(1 \mathrm{mg} / \mathrm{kg})$ & $3.08 \pm 0.08$ & $5.50 \pm 0.18$ & $7.42 \pm 0.15$ & $9.67 \pm 0.17$ & $9.83 \pm 0.11$ \\
\hline Physostigmine $50 \mu \mathrm{g} / \mathrm{kg}$ & $2.83 \pm 0.11$ & $3.08 \pm 0.15$ & $3.08 \pm 0.15$ & $3.00 \pm 0.13$ & $3.17 \pm 0.11$ \\
\hline Physostigmine $100 \mu \mathrm{g} / \mathrm{kg}$ & $3.17 \pm 0.11$ & $3.17 \pm 0.11$ & $4.08 \pm 0.27$ & $6.25 \pm 0.28$ & $7.50 \pm 0.18$ \\
\hline Physostigmine $200 \mu \mathrm{g} / \mathrm{kg}$ & $3.17 \pm 0.11$ & $3.92 \pm 0.33$ & $6.25 \pm 0.21$ & $8.00 \pm 0.18$ & $9.50 \pm 0.18$ \\
\hline Physostigmine $50 \mu \mathrm{g} / \mathrm{kg}+$ Morphine $0.1 \mathrm{mg} / \mathrm{kg}$ & $3.17 \pm 0.11$ & $3.08 \pm 0.15$ & $4.08 \pm 0.27$ & $6.33 \pm 0.17$ & $7.25 \pm 0.11$ \\
\hline
\end{tabular}

Subcutaneous (s.c) administration of Physostigmine increased the tail flick latency period $(\mathrm{sec})($ Mean $\pm \mathrm{SE})$ in the doses of $100 \mu \mathrm{g} / \mathrm{kg}$ and $200 \mu \mathrm{g} / \mathrm{kg}$ at $60 \mathrm{~min}$ $(6.25 \pm 0.28, \quad 8.00 \pm 0.18$ respectively) and $90 \mathrm{~min}$ $(7.50 \pm 0.18,9.50 \pm 0.18$ respectively) interval incomparison to control (NS) treatment group $(3.17 \pm 0.11$, $3.33 \pm 0.11$ respectively) indicating Physostigmine produces antinociceptive effect in tail flick test. However there is no much increase in the tail flick latency in the Physostigmine $50 \mu \mathrm{g} / \mathrm{kg}$ (s.c) treatment at 60 and $90 \mathrm{~min}$ $(2.83 \pm 0.11,3.08 \pm 0.15$ respectively) in comparison to control (NS) treatment group $(3.17 \pm 0.11,3.33 \pm 0.11$ respectively) (Table 2). 
Table 4: Maximal possible effect (MPE) in \% of increased tail flick latency of physostigmine.

\begin{tabular}{|llllllll|}
\hline SL NO & NS & MOR 0.1 & MOR 1 & PHYSO50 & PHYSO100 & PHYSO200 & $\begin{array}{l}\text { PHYSO50 + } \\
\text { MOR 0.1 }\end{array}$ \\
\hline 1 & 7.14 & 6.67 & 100.00 & 6.67 & 57.14 & 85.71 & 64.29 \\
\hline 2 & 6.67 & 1.33 & 100.00 & 7.14 & 61.54 & 100.00 & 61.54 \\
\hline 3 & 7.14 & 7.14 & 92.86 & 6.67 & 71.43 & 92.86 & 57.14 \\
\hline 4 & 7.14 & 7.14 & 100.00 & 0.00 & 71.43 & 100.00 & 64.29 \\
\hline 5 & 0.00 & 0.00 & 92.86 & 0.00 & 61.54 & 92.31 & 53.85 \\
\hline 6 & 7.14 & 7.14 & 100.00 & 7.14 & 57.14 & 85.71 & 57.14 \\
\hline Total & 35.23 & 29.42 & 585.17 & 27.62 & 380.22 & 556.59 & 358.25 \\
\hline Mean & 5.87 & 4.90 & 97.53 & 4.60 & 63.37 & 92.77 & 59.71 \\
\hline SD & 2.88 & 3.31 & 3.83 & 3.57 & 6.55 & 6.39 & 4.31 \\
\hline SE & 1.18 & 1.35 & 1.56 & 1.46 & 2.67 & 2.61 & 1.76 \\
\hline
\end{tabular}

NS - Normal Saline; MOR 0.1 - Morphine $0.1 \mathrm{mg} / \mathrm{kg}$; MOR 1 - Morphine $1 \mathrm{mg} / \mathrm{kg}$; PHYSO 50 - Physostigmine $50 \mu \mathrm{g} / \mathrm{kg}$; PHYSO 100 - Physostigmine $100 \mu \mathrm{g} / \mathrm{kg}$; PHYSO 200 - Physostigmine $200 \mu \mathrm{g} / \mathrm{kg}$; PHYSO 1 + MOR 0.1 - Physostigmine $50 \mu \mathrm{g} / \mathrm{kg}$ + Morphine $0.1 \mathrm{mg} / \mathrm{kg}$

Intraperitoneal (i.p) administration of Morphine in the antinociceptive dose of $1 \mathrm{mg} / \mathrm{kg}$ produced increase in the tail flick latency $15,30,60,90 \mathrm{~min}(5.50 \pm 0.18$, $7.42 \pm 0.15, \quad 9.67 \pm 0.17, \quad 9.83 \pm 0.11$ respectively) in comparison to control (NS) treatment group (3.08 \pm 0.15 , $3.25 \pm 0.11,3.17 \pm 0.11,3.33 \pm 0.11$ respectively) (Table 2 ).

Table 5: Comparison of mean \pm S.E. and S.D. of MPE in \% of tail flick latency of Physostigmine.

\begin{tabular}{|c|c|c|}
\hline Groups & Mean \pm SE & $\begin{array}{l}\text { Std. } \\
\text { Deviation }\end{array}$ \\
\hline $\begin{array}{l}\text { Normal Saline (Control) } \\
(\mathrm{NS})\end{array}$ & $5.87 \pm 1.18$ & 2.88 \\
\hline $\begin{array}{l}\text { Morphine } 0.1 \mathrm{mg} / \mathrm{kg} \\
\text { (MOR 0.1) }\end{array}$ & $4.90 \pm 1.35$ & 3.31 \\
\hline $\begin{array}{l}\text { Morphine } 1 \mathrm{mg} / \mathrm{kg} \text { (MOR } \\
\text { 1) }\end{array}$ & $97.53 \pm 1.56$ & 3.83 \\
\hline $\begin{array}{l}\text { Physostigmine } 50 \mu \mathrm{g} / \mathrm{kg} \\
\text { (PHYSO 50) }\end{array}$ & $4.60 \pm 1.46$ & 3.57 \\
\hline $\begin{array}{l}\text { Physostigmine } 100 \mu \mathrm{g} / \mathrm{kg} \\
\text { (PHYSO 100) }\end{array}$ & $63.37 \pm 2.67$ & 6.55 \\
\hline $\begin{array}{l}\text { Physostigmine } 200 \mu \mathrm{g} / \mathrm{kg} \\
\text { (PHYSO 200) }\end{array}$ & $92.77 \pm 2.61$ & 6.39 \\
\hline $\begin{array}{l}\text { Physostigmine } 50 \mu \mathrm{g} / \mathrm{kg}+ \\
\text { Morphine } 0.1 \mathrm{mg} / \mathrm{kg} \\
(\text { PHYSO } 50+\text { MOR 0.1) }\end{array}$ & $59.71 \pm 1.76$ & 4.31 \\
\hline
\end{tabular}

However there is no much increase in the tail flick latency in the Morphine $0.1 \mathrm{mg} / \mathrm{kg}$ (i.p) treatment at 15 , 30,60 and $90 \mathrm{~min}(3.08 \pm 0.15,3.25 \pm 0.11,3.17 \pm 0.11$, $3.33 \pm 0.11$ respectively) in comparison to control (NS) treatment group $(3.08 \pm 0.15,3.25 \pm 0.11,3.17 \pm 0.11$, $3.33 \pm 0.11$ respectively) (Table 2 ).
Combination treatment of low doses of both Physostigmine $50 \mu \mathrm{g} / \mathrm{kg}+$ Morphine $0.1 \mathrm{mg} / \mathrm{kg}$ increased the tail flick latency at 60 and $90 \mathrm{~min}(6.33 \pm 0.17$, $7.08 \pm 0.15$ respectively) in-comparison to control (NS) treatment group $(3.17 \pm 0.11,3.33 \pm 0.11$ respectively), Physostigmine $50 \quad \mu \mathrm{g} / \mathrm{kg} \quad(3.00 \pm 0.13, \quad 3.17 \pm 0.11$ respectively) alone or Morphine $0.1 \mathrm{mg} / \mathrm{kg}(3.17 \pm 0.11$, $3.33 \pm 0.11$ respectively) alone (Table 2 ).

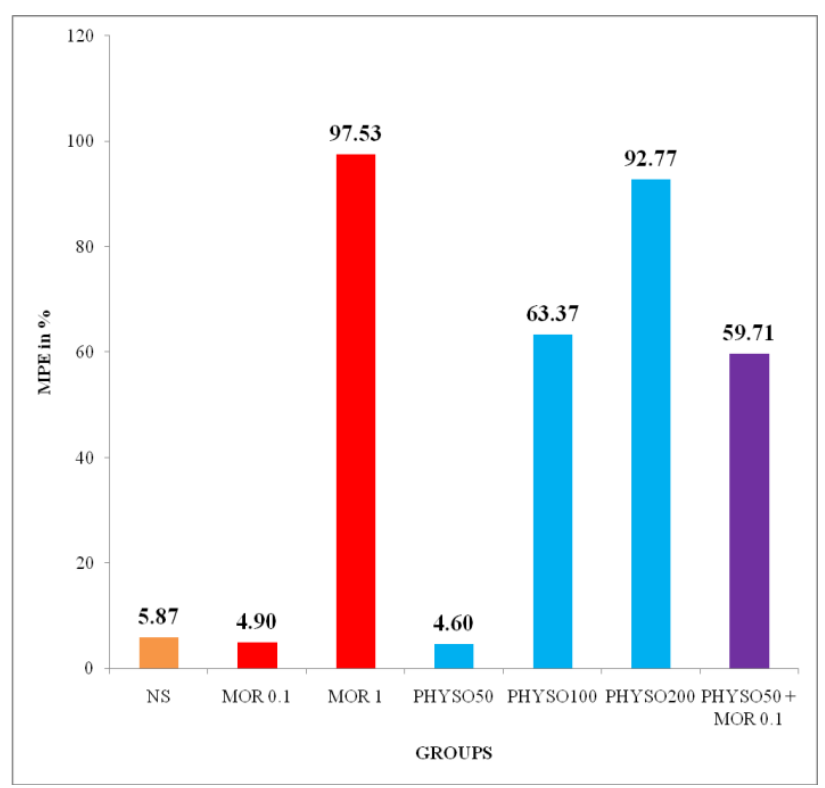

Figure 1: MPE in \% of increased tail flick latency of physostigmine.

From the observed data the maximum possible effect in percentage of increased tail flick latency at $90 \mathrm{~min}$ is calculated. 
Maximum Possible Effect (MPE) in percentage $=$ (post drug latency - pre drug latency/ cut-off time - pre drug latency) x 100 (Table 3).

Maximal possible increase (MPE) in tail flick latency (\%) at $90 \mathrm{~min}$ was calculated in Physostigmine $100 \mu \mathrm{g} / \mathrm{kg}$, Physostigmine $200 \mu \mathrm{g} / \mathrm{kg}$, Morphine $1 \mathrm{mg} / \mathrm{kg}$ and combination treatment of Physostigmine $50 \mu \mathrm{g} / \mathrm{kg}+$ Morphine $\quad 0.1 \quad \mathrm{mg} / \mathrm{kg} \quad(63.37 \pm 2.67, \quad 92.77 \pm 2.61$,
$97.53 \pm 1.56,59.71 \pm 1.76$ respectively) which is more and statistically significant in comparison to control group $(5.87 \pm 1.18)$ (Table no.3). These results suggest that Physostigmine $100 \mu \mathrm{g} / \mathrm{kg}$, Physostigmine $200 \mu \mathrm{g} / \mathrm{kg}$, Morphine $1 \mathrm{mg} / \mathrm{kg}$ and combination treatment of Physostigmine $50 \mu \mathrm{g} / \mathrm{kg}+$ Morphine $0.1 \mathrm{mg} / \mathrm{kg}$ can produce significant antinociceptive effect in the tail flick test model in Albino Rats (Table 3).

Table 6: Intergroup comparison of MPE in \% of physostigmine by one way ANOVA test.

\begin{tabular}{|llllll|} 
& Sum of Squares & df & Mean Square & F & Sig. \\
\hline Between Groups & 62028.983 & 6.00 & 10338.164 & 485.492 & $0.0001 * * *$ \\
\hline Within Groups & 745.297 & 35.00 & 21.294 & & \\
\hline Total & 62774.281 & 41.00 & & & \\
\hline
\end{tabular}

Further intergroup comparison of MPE (\%) showed that Physostigmine $200 \mu \mathrm{g} / \mathrm{kg}(92.77 \pm 2.61)$ is comparable with Morphine $1 \mathrm{mg} / \mathrm{kg}(97.53 \pm 1.56)$ (Table no.3) indicating that Physostigmine $200 \mu \mathrm{g} / \mathrm{kg}$ is more potent than Morphine $1 \mathrm{mg} / \mathrm{kg}$. MPE (\%) of combination group Physostigmine $50 \mu \mathrm{g} / \mathrm{kg}+$ Morphine $0.1 \mathrm{mg} / \mathrm{kg}$ $(59.71 \pm 1.76)$ is significantly more than Physostigmine 50 $\mu \mathrm{g} / \mathrm{kg} \quad(4.60 \pm 1.46)$ alone or Morphine $0.1 \mathrm{mg} / \mathrm{kg}$ $(4.90 \pm 1.35)$ alone indicating Physostigmine can potentiate antinociceptive effect of Morphine (Table 3).

\section{DISCUSSION}

In the present study, three graded doses of Physostigmine $(50 \mu \mathrm{g} / \mathrm{kg}, 100 \mu \mathrm{g} / \mathrm{kg}, 200 \mu \mathrm{g} / \mathrm{kg})$ (s.c) and combination of Physostigmine (50 $\mu \mathrm{g} / \mathrm{kg})$ (s.c) + sub-analgesic dose of Morphine $(0.1 \mathrm{mg} / \mathrm{kg})$ (i.p) was compared with standard drug Morphine analgesic dose (1 mg/kg) (i.p) and control group Normal Saline (NS) (0.5ml) (i.p).

Tail flick latency $(\mathrm{sec})$ was recorded at $0 \mathrm{~min}, 15 \mathrm{~min}, 30$ min, $60 \mathrm{~min}$ and $90 \mathrm{~min}$ after drug administration. Subcutaneous (s.c) administration of Physostigmine increased the tail flick latency period $(\mathrm{sec})($ Mean $\pm \mathrm{SE}$ ) in the doses of $100 \mu \mathrm{g} / \mathrm{kg}$ and $200 \mu \mathrm{g} / \mathrm{kg}$ at $60 \mathrm{~min}$ $(6.25 \pm 0.28, \quad 8.00 \pm 0.18$ respectively) and $90 \mathrm{~min}$ $(7.50 \pm 0.18, \quad 9.50 \pm 0.18$ respectively) interval incomparison to control (NS) treatment group $(3.17 \pm 0.11$, $3.33 \pm 0.11$ respectively), indicating Physostigmine produces antinociceptive effect in tail flick test.

Intraperitoneal (i.p) administration of Morphine in the antinociceptive dose of $1 \mathrm{mg} / \mathrm{kg}$ produced increase in the tail flick latency $(\mathrm{sec})$ at 15, 30, 60, $90 \mathrm{~min}(5.50 \pm 0.18$, $7.42 \pm 0.15, \quad 9.67 \pm 0.17, \quad 9.83 \pm 0.11$ respectively) in comparison to control (NS) treatment group (3.08 \pm 0.15 , $3.25 \pm 0.11,3.17 \pm 0.11,3.33 \pm 0.11$ respectively.
Combination treatment of low doses of both Physostigmine $50 \mu \mathrm{g} / \mathrm{kg}+$ Morphine $0.1 \mathrm{mg} / \mathrm{kg}$ increased the tail flick latency at 60 and $90 \mathrm{~min}(6.33 \pm 0.17$, $7.08 \pm 0.15$ respectively) in-comparison to control (NS) treatment group $(3.17 \pm 0.11,3.33 \pm 0.11$ respectively) or Physostigmine $\quad 50 \mu \mathrm{g} / \mathrm{kg} \quad(3.00 \pm 0.13, \quad 3.17 \pm 0.11$ respectively) alone or Morphine $0.1 \mathrm{mg} / \mathrm{kg}(3.17 \pm 0.11$, $3.33 \pm 0.11$ respectively) alone.

Maximal possible effect (MPE) in tail flick latency in percentage $(\%)$ at $90 \mathrm{~min}$ was calculated in Physostigmine $100 \mu \mathrm{g} / \mathrm{kg}$, Physostigmine $200 \mu \mathrm{g} / \mathrm{kg}$, Morphine $1 \mathrm{mg} / \mathrm{kg}$ and combination treatment of Physostigmine $50 \mu \mathrm{g} / \mathrm{kg}+$ Morphine $0.1 \mathrm{mg} / \mathrm{kg}$ $(63.37 \pm 2.67, \quad 92.77 \pm 2.61, \quad 97.53 \pm 1.56, \quad 59.71 \pm 1.76$ respectively) which is more and statistically significant in comparison to control group $(5.87 \pm 1.18)$. These results suggest that Physostigmine $100 \mu \mathrm{g} / \mathrm{kg}$, Physostigmine $200 \mu \mathrm{g} / \mathrm{kg}$, Morphine $1 \mathrm{mg} / \mathrm{kg}$ and combination treatment of Physostigmine $50 \mu \mathrm{g} / \mathrm{kg}+$ Morphine $0.1 \mathrm{mg} / \mathrm{kg}$ can produce significant antinociceptive effect in the tail flick test model in albino rats.

Further intergroup comparison of MPE (\%) showed that Physostigmine $200 \mu \mathrm{g} / \mathrm{kg}(92.77 \pm 2.61)$ is comparable with Morphine $1 \mathrm{mg} / \mathrm{kg}(97.53 \pm 1.56)$ indicating that Physostigmine is more potent than Morphine. MPE (\%) of combination group Physostigmine $50 \mu \mathrm{g} / \mathrm{kg}+$ Morphine $0.1 \mathrm{mg} / \mathrm{kg}(59.71 \pm 1.76)$ is significantly more than Physostigmine $50 \mu \mathrm{g} / \mathrm{kg}(4.60 \pm 1.46)$ alone or Morphine $0.1 \mathrm{mg} / \mathrm{kg} \quad(4.90 \pm 1.35)$ alone indicating Physostigmine can potentiate antinociceptive effect of Morphine.

The results of the present study indicated that cholinergic drugs can produce antinociceptive effect in the tail flick test. Nemirovsky et al $(1985,1988,1990)$, Yaksh et al (1985, 1995), Gillberg et al (1986, 1989, 1990 1991), Gordh et al (1989) also reported antinociceptive effect of 
cholinomimetics and anticholinesterases in the experimental animal models. ${ }^{16-24}$

The results of the present study indicated that Physostigmine can potentiate the antinociceptive effect of low dose of Morphine in tail flick test model. Peterson J et al, Beilin B et al also reported enhancement of analgesic effect of Morphine by Physostigmine in postoperative patients. ${ }^{25,26}$

\section{CONCLUSION}

Present study suggests that there is involvement of cholinergic system in antinociceptive action which is evaluated by administration of Physostigmine in tail flick test in albino rats.

Physostigmine (100 $\mu \mathrm{g} / \mathrm{kg} \quad \& \quad 200 \mu \mathrm{g} / \mathrm{kg}) \quad$ (s.c) has antinociceptive action by tail flick test in albino rats.

The antinociceptive effect of Physostigmine $200 \mu \mathrm{g} / \mathrm{kg}$ is comparable to Morphine $1 \mathrm{mg} / \mathrm{kg}$ in Tail Flick Test model, indicating that Physostigmine is more potent than Morphine.

Combination of low doses of Physostigmine $(50 \mu \mathrm{g} / \mathrm{kg})$ potentiated antinociceptive effect of low dose of Morphine $(0.1 \mathrm{mg} / \mathrm{kg})$ in Tail Flick Test model, indicating that cholinergic drugs like Physostigmine can be combined with Morphine for enhancement of Morphine action.

\section{ACKNOWLEDGEMENTS}

I am thankful to Dr. Rahul P. Bhavasar, Mr. Bapurao M. Bite and Dr. Suyog S. Chopade for their kind cooperation during preparation of this manuscript.

\section{Funding: No funding sources}

Conflict of interest: None declared

Ethical approval: The study was approved by the Institutional Animal Ethics Committee

\section{REFERENCES}

1. Chaturvedi S, Chaturvedi A. Post operative pain and its management. Indian $\mathbf{J}$ Crit Care Med. 2007;11(4):204-11.

2. Chabal C, Jacobsen L, Chaney EF, Mariano AJ. Narcotic for chronic pain: yes or no? A useless dichotomy. APS J. 1992;1(4):276-81.

3. Basbaum AI, Fields HL. Endogenous pain control systems: brainstem spinal pathways and endorphin circuitry. Annu Rev Neurosci. 1984;7:309-38.

4. Gebhart GF. Descending modulation of pain. Neurosci Biobehav Rev. 2004;27:729-37.

5. Ren K, Dubner R. Descending modulation in persistent pain: an update. Pain. 2002;100:1-6.

6. Millan MJ. Descending control of pain. Prog Neurobiol. 2002;66:355-474.
7. Pertovaara A. Noradrenergic pain modulation. Prog Neurobiol. 2006;80:53-83.

8. Mason P. Deconstructing endogenous pain modulations. J Neurophysiol. 2005;94:1659-63.

9. Yang XF, Xiao Y, Xu MY. Both endogenous and exogenous ACh plays antinociceptive role in hippocampus CA1 of rats. J Neural Transm. 2008;115.1-6.

10. Mojtahedin A, Tamaddonfard E, Zanbouri A. Role of central muscarinic cholinergic receptors in the formalin-induced pain in rats. Indian $\mathrm{J}$ Pharmacol. 2009;41:144-7.

11. Li B, Duysen EG, Volpicelli-Daley LA, Levey AI, Lockridge O. Regulation of muscarinic acetylcholine receptor function in acetylcholinesterase knockout mice. Pharmacol Biochem Behav. 2003;74:977-86.

12. Ghelardini C, Galeotti N, Bartolini A. Loss of muscarinic antinociception by antisense inhibition of M1 receptors. Br J Pharmacol. 2000;129:1633-40.

13. Chen SR, Wess J, Pan HL. Functional activity of the M2 and M4 receptor subtypes in the spinal cord studied with muscarinic acetylcholine receptor knockout mice. J Pharmacol Exp Ther. 2005;313:765-70.

14. McKenna JE, Melzack R. Blocking NMDA receptors in the hippocampal dentate gyrus with AP5 produces analgesia in the formalin pain test. Exp Neurol. 2001;172:92-9.

15. Buno W, Cabezas C, de Fernandez Sevilla D. Presynaptic muscarinic control of glutamatergic synaptic transmission. J Mol Neurosci. 2006;30:1614.

16. Petersson J, Gordh TE, Hartvig P. A double-blind trial of the analgesic properties of physostigmine in postoperative patients. Acta Anesthesiol Scand. 1986;30:283-8.

17. Hood DD, Eisenach JC. Phase I safety assessment of spinal neostigmine in volunteers. Anesthesiology. 1994;81:A926.

18. Hood DD, Eisenach JC. Side effects and analgesia from spinal neostigmine injected through a whitacre needle. Anesthesiology. 1994;81:A927.

19. Weinstock M, Davidson JT, Rosin AJ. Effect of physostigmine on morphine-induced postoperative pain and somnolence. $\mathrm{Br} \mathrm{J}$ Anaesthesiol. 1982;54:429-32.

20. Woolf NJ. Cholinergic systems in mammalian brain and spinal cord. Prog Neurobiol. 1991;37:475-524.

21. Beilin B, Bessler H, Papismedov L, Weinstock M, Shavit Y. Continuous physostigmine combined with morphine-based patient-controlled analgesia in the postoperative period. Acta Anaesthesiol Scand. 2005;49 (1):78-84.

22. Fugita K, Nagata Y. Effects of dorsal root section and occlusion of dorsal spinal artery on the neurotransmitter candidates in rat spinal cord. Neurochem Res. 1989;14:399-404.

23. McGeer PL, McGeer EG, Singh VR. Choline acetyltransferase localization in the central nervous 
system by immunohistochemistry. Brain Res. 1974;81:373-9.

24. Dawson GR, Iversen SD. The effect of novel cholinterase inhibitors and selective muscarinic receptor agonists in tests of reference and working memory. Behavioral Brain Res. 1993;57:143-53.

25. Jiao RS, Yang CX, Zhang Y, Xu MY, Yang XF. Cholinergic mechanism involved in the nociceptive modulation of dentate gyrus. Biochem Biophys Res Commun. 2009;379:975-9.
26. Perry EK, Smith CJ, Perry RH. Regional distribution of muscarinic and nicotinic cholinergic receptor binding activities in the human brain. J Chem Neuroanat. 1989;2:189-99.

Cite this article as: Bhavasar RP, Chaudhari DR, Bite BM, Chopade SS. Study of anti-nociceptive potential of physostigmine and its combination with morphine in albino rats. Int $\mathrm{J}$ Basic Clin Pharmacol 2015;4:1054-60. 